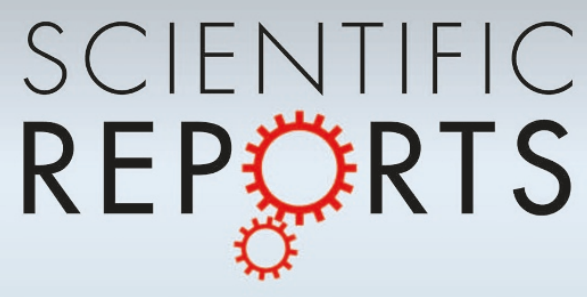

OPEN

SUBJECT AREAS:

CONSERVATION

BIOLOGY

ENVIRONMENTAL ECONOMICS

Received

14 September 2014

Accepted

6 November 2014

Published

12 February 2015

Correspondence and requests for materials should be addressed to

U.R.S. (r.sumaila@

fisheries.ubc.ca)

\section{Winners and losers in a world where the high seas is closed to fishing}

\author{
U. Rashid Sumaila', Vicky W. Y. Lam², Dana D. Miller', Louise Teh', Reg A. Watson ${ }^{3}$, Dirk Zeller², \\ William W. L. Cheung ${ }^{4}$, Isabelle M. Côté ${ }^{5}$, Alex D. Rogers ${ }^{6}$, Callum Roberts' ${ }^{7}$ Enric Sala ${ }^{8} \&$ Daniel Pauly ${ }^{2}$
}

${ }^{1}$ Fisheries Economics Research Unit, Fisheries Centre, University of British Columbia, Vancouver, British Columbia, V6T 1Z4, Canada, ${ }^{2}$ Sea Around Us, Fisheries Centre, University of British Columbia, Vancouver, British Columbia, V6T 1Z4, Canada, ${ }^{3}$ Institute for Marine and Antarctic Studies (IMAS), University of Tasmania, Private Bag 129 Hobart, Tasmania, Australia 7001, ${ }^{4}$ Changing Ocean Research Unit, Fisheries Centre, University of British Columbia, Vancouver, British Columbia, V6T 1Z4, Canada, ${ }^{5}$ Department of Biological Sciences, Simon Fraser University, Burnaby, British Columbia, V5A 1S6, Canada, ${ }^{6}$ Department of Zoology, University of Oxford, South Parks Road, Oxford, OX1 3PS, UK, ${ }^{7}$ Environment Department, University of York, York, YO 10 5DD, UK, ${ }^{8}$ National Geographic Society, Washington, DC, USA.

Fishing takes place in the high seas and Exclusive Economic Zones (EEZs) of maritime countries. Closing the former to fishing has recently been proposed in the literature and is currently an issue of debate in various international fora. We determine the degree of overlap between fish caught in these two areas of the ocean, examine how global catch might change if catches of straddling species or taxon groups increase within EEZs as a result of protection of adjacent high seas; and identify countries that are likely to gain or lose in total catch quantity and value following high-seas closure. We find that $<0.01 \%$ of the quantity and value of commercial fish taxa are obtained from catch taken exclusively in the high seas, and if the catch of straddling taxa increases by $18 \%$ on average following closure because of spillover, there would be no loss in global catch. The Gini coefficient, which measures income inequality, would decrease from 0.66 to 0.33 . Thus, closing the high seas could be catch-neutral while inequality in the distribution of fisheries benefits among the world's maritime countries could be reduced by $50 \%$.

F ishing, arguably one of the most valuable aquatic ecosystem provisioning services to people, takes place in coastal areas, i.e., within Exclusive Economic Zones (EEZs), and in the high seas. EEZs are areas of the global ocean within 200 nautical miles of the coast of maritime countries which claim sole rights to the resources found within them. In contrast, the high seas are international waters and are therefore 'owned' by all citizens of the world. Over the past decades, fishing has expanded into the high seas because of overexploitation of coastal waters, increasing demand for fish driven by increasing world population and rising incomes, provision of government subsidies, and technological innovation ${ }^{1,2}$.

The increasing exploitation of fish on the high seas has caused concern among scientists, economists, lawyers, governments, non-governmental organizations and the public for several reasons. Inadequate management has led to overfishing of many economically important fish stocks ${ }^{3}$ and the fisheries exploiting these resources have been associated with by-catch of threatened or vulnerable species and habitat destruction ${ }^{4}$. The current status of a number of highly migratory, pelagic species such as tunas and billfishes is particularly worrying. Overall, stocks of tunas and their relatives have declined on average by $60 \%$ during the last half century and the majority of these stocks are either fully or overexploited ${ }^{5}$. Deep-sea fishes are also a serious concern. The depth of the high seas, with little light and food available, provides habitat for fishes that are often long lived and slow growing, characteristics that make them vulnerable to overfishing ${ }^{6}$. Additionally, despite the technological advances that have allowed us to fish at great depths and the new knowledge we are currently accumulating, the vast majority of the deep ocean remains unexplored and poorly understood ${ }^{7}$. The ecological impacts of deep-sea fishing activities are also largely unknown ${ }^{8}$.

Economic concerns centre on the fact that many fisheries exploiting high-seas resources would not be viable without government subsidies, and socially, only provide jobs and significant incomes to relatively few ${ }^{9}$. From a legal standpoint, both fish and fishers of the high seas are the least protected by international agreements ${ }^{10}$, leaving those working on high-seas vessels vulnerable to exploitative treatment and unsafe working conditions. The United Nations Convention on the Law of the Sea (UNCLOS) was signed in 1982, when it was thought that the impact of fishing would not be significant in the high seas because of technological limitations and this area's generally low biological productivity ${ }^{11}$. Now, everything we know about deep-sea habitats and fishing methods 
such as bottom trawling suggest that the two are incompatible and mounting evidence supports the view that deep-sea ecosystems are in need of urgent protection ${ }^{8}$. Large marine protected areas (MPAs) in the high seas are of increasing interest $\mathrm{t}^{9,12,13}$ and their benefits could be far-reaching. Currently, Regional Fisheries Management Organizations (RFMOs) are implementing fisheries closures to protect vulnerable marine ecosystems in some parts of the high seas. However, there is no effective, coherent management framework for this important part of the global ocean ${ }^{14}$ and RFMOs are generally failing to meet the larger mandates under the United Nations and even their own Conventions ${ }^{10,15}$. As of 2010, two thirds of all stocks of known status under RFMO management were depleted or being overfished $^{3}$.

Importantly, the depletion of high-seas stocks can influence the availability of fish to coastal fleets. We now know that many ocean predators forage in both EEZs and the high seas in the course of a year, exploiting different regions of high prey availability ${ }^{16}$. Some 'high-seas' species therefore straddle EEZ boundaries; hence, mismanaging the high seas also can have direct repercussions on coastal communities and ecosystems. The degree of overlap between the fish currently caught in the high seas and the EEZs has to date not been assessed, but it potentially has important ramifications for fisheries.

White \& Costello $^{17}$ suggested positive economic benefits from closing the high seas because although the management of fisheries that operate in EEZs is far from perfect, these fisheries are generally relatively better managed than high-seas fisheries ${ }^{18}$. Our goal here is to examine this idea with empirical fisheries data to assess the impacts of a high-seas closure on global fisheries catches and values, and the economic consequences for individual countries. First, we analyze global fish catch and landed values to determine how much fish is caught in the high seas versus in EEZs. Specifically, we estimate the global average annual catch and landed values for each species/ taxon group caught (i) exclusively in the high seas; (ii) exclusively in EEZs; and (iii) in both the high seas and the EEZs (i.e., straddling taxa). Second, we examine how the availability of fisheries resources to coastal countries could change following a high-seas closure, and identify the countries that stand to gain or lose, considering potential spillover of biomass from closed areas and lost fishing opportunities in the high seas. We ask what percentage increase in the catch of straddling taxa would make closing the high seas catch-neutral. The result obtained is compared with a range of potential increases in these catches predicted by White \& Costello ${ }^{17}$.To explore the sensitivity of our results to uncertainty and our assumptions, we simulate various scenarios of increasing total catch of straddling taxa with the closure of the high seas. We then identify winners and losers in terms of catch and landed value by country or political entity under the different scenarios studied. Finally, we assess the distribution of these benefits under the status quo and with a closure by calculating the Gini coefficient, which we use to measure the extent of landed value disparity among countries or political entities.

\section{Results}

Distribution of catches. Of the 1,406 taxa analyzed, 585 were caught both within EEZs and high seas, while 802 were caught only within EEZs and only 19 exclusively in the high seas (Fig. 1, Supplementary Table 1). In other words, $\sim 42 \%$ of the taxa can be considered 'straddling', while only $\sim 1.5 \%$ are exclusively high seas. The importance of straddling taxa increases greatly when viewed in terms of global catch amount (67\%) and landed value (72\%) (Fig. 1).

Between 2000 and 2010, an average of 10 million $t$ of fish was caught annually in the high seas (Table 1 ). This represents $\sim 12 \%$ of the global average annual marine fisheries catch of 80 million $t$. The landed value of this catch is estimated at about US\$16 billion annually (Table 1), which makes up about $15 \%$ of the total global marine landed value of about US $\$ 109$ billion $^{19}$. In contrast, the high seas represent approximately $58 \%$ of the global ocean surface. The top 10 taxa caught in the high seas generate average annual catch and landed values of 7 million $t$ and US\$12 billion, respectively (Table 1). Excluding small pelagic fishes, which are mainly coastal, the 10 leading high-seas fishing nations together land $62 \%$ of the high-seas catch and capture $71 \%$ of the landed values, respectively (Table 2 ). These numbers immediately raise equity and social concerns - a few countries take a large proportion of the benefits from an internationally shared area.

Importantly, of the annual average 10 million t of high-seas catch, only 3,000 $\mathrm{t}$ (annual landed value of US $\$ 3$ million) consist of taxa exclusively caught in the high seas (Table 1, Fig. 1). In contrast, species that are caught only within EEZs total 26.4 million $t$, generating US $\$ 30.4$ billion annually (Fig. 1). The bulk of global fish catch and landed value are of taxa caught in both the high seas and the EEZs of maritime countries, amounting to an average of 53.6 million $\mathrm{t}$ and US\$78.2 billion per year, respectively (Fig. 1). Many of these straddling taxa are oceanodromous taxa with widespread distributions (Supplementary Table 1). These results illustrate strong ecological and economic sharing between EEZs and the high seas.

Net effect on fisheries catches of closing the high seas. We find that closure of the high seas would not lead to losses in aggregate global catch if catches of straddling taxa within EEZs following the closure increase by at least $18 \%$, on average, due to the spillover of biomass from the closed high seas areas. This percentage is below the modelled example estimate of $42 \%$ catch increase explored in White \& Costello ${ }^{17}$ and at the low end of the predicted minimum and maximum range of 10 to $70 \%$ that was associated with this
19

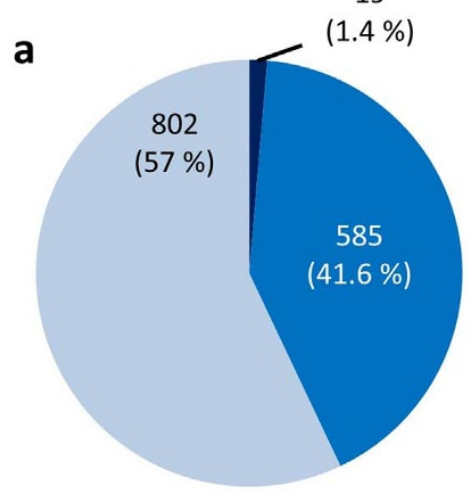

3

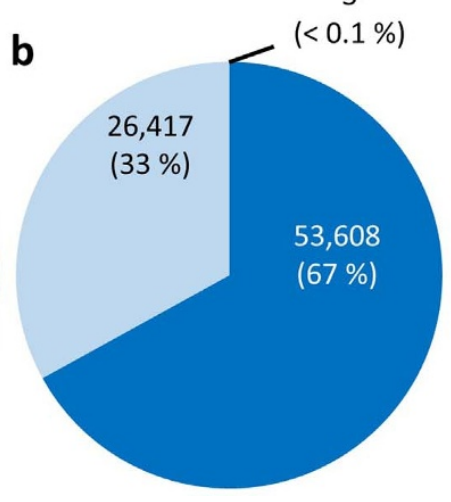

3

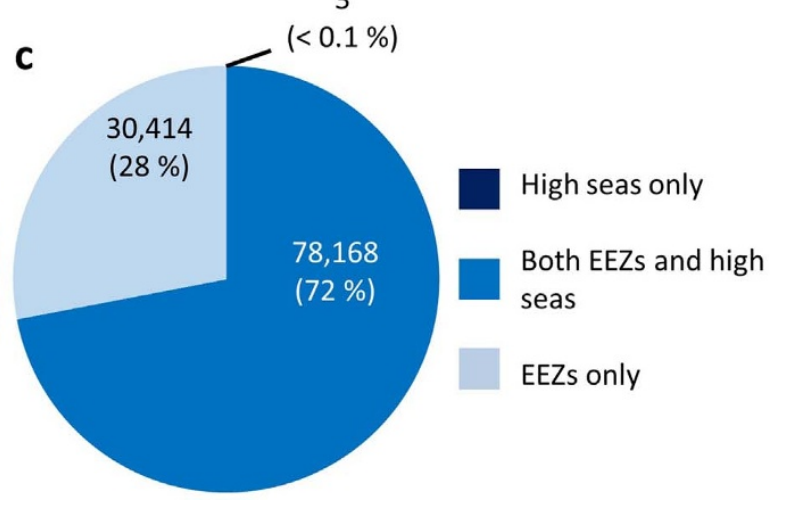

Figure $1 \mid$ Average annual portions of taxa taken from the high seas only, from both the high seas and Exclusive Economic Zones (EEZs), and from EEZs only based on global catch statistics 2000-2010. (a), Number of taxa (total =1,406); (b), Catch quantities (thousand t) (total = 80,028); and c, Landed values (million US\$) (total $=108,585)$. 
Table 1 | Top taxa by average annual landed value (2000-2010)*

\begin{tabular}{|c|c|c|c|c|}
\hline Taxa & $\begin{array}{l}\text { Average high-seas landed value } \\
\text { (million US\$) }\end{array}$ & $\%$ of global landed value & Average high-seas catch (thousand t) & $\%$ of global catch \\
\hline Small pelagic fishes & 3,860 & 20 & 2,002 & 22 \\
\hline Yellowfin tuna & 1,964 & 72 & 972 & 72 \\
\hline Skipjack tuna & 1,738 & 64 & 1,592 & 64 \\
\hline Argentine shortfin squid & 480 & 62 & 346 & 62 \\
\hline Albacore & 457 & 70 & 200 & 73 \\
\hline Marine molluscs & 381 & 27 & 231 & 27 \\
\hline Jumbo flying squid & 316 & 51 & 297 & 49 \\
\hline Other species & 3,899 & 5 & 2,961 & 5 \\
\hline Total for top ten & 11,971 & & 7,008 & \\
\hline Total for all taxa & 15,869 & & 9,970 & \\
\hline
\end{tabular}

modelled scenario. With an $18 \%$ increase in the catches of straddling taxa, 120 maritime countries experience net gains in the landed values of their fisheries catches, 65 countries experience net losses and seven countries experience neither gains nor losses (Fig. 2, Supplementary Table 2). In addition, the global distribution of landed values derived from a high seas closure improves markedly, as the Gini coefficient declines from 0.66 (close to the coefficient estimated for incomes in South Africa, the country with the most unequal income distribution in the world at 0.7 ) currently to 0.33 (similar to Japan's score) ${ }^{20}$ (Fig. 3). The countries or political entities that would benefit the most from a closure are the USA, Guam and the UK, all with gains in total landed values of over US $\$ 250$ million a year, while the countries that would lose the most are South Korea, Taiwan and Japan, each with losses of over US\$800 million per year (Supplementary Table 2).

Using the predicted $42 \%$ yield increase by White and Costello ${ }^{17}$, the global catch and landed values increase by 11 million $\mathrm{t}$ and US\$13 billion (16\% and $15 \%$ higher, respectively) per year relative to the status quo. In this scenario, 135 countries experience net gains in landed values, 50 countries experience net losses, and seven countries experience neither gains nor losses (Supplementary Table 2). Given this scenario, the countries or political entities that would benefit the most from a closure are the USA, China and Japan, all with gains in total landed values of over US\$1.2 billion a year. On the other hand, those that are predicted to lose the most are Taiwan and South Korea, each with losses of over US\$500 million (Supplementary Table 2). Considering groups of countries or political entities with economic or geographic similarities, our analyses suggest that European Union (EU) Member States, the Group of Eight (G8) countries, members of the Organisation for Economic Co-Operation and Development (OECD) and the Least Developed Countries, as identified by the United Nations (UN), all fare better in terms of forecasted average percentage gains than all countries considered together under every scenario examined (Supplementary Table 3). The top 10 countries that currently catch the most by value in the high seas, the Small Island Developing States (SIDS), as identified by the UN, and the group of 'Flag of Convenience (FoC) countries', i.e., those for which $50 \%$ or more of the fishing vessels in the fleet are flying the flag of a state that does not match the state of vessel owner control or residence (Supplementary Table 4), all fare worse than all countries considered together under every scenario examined. Note that a number of SIDS provide Flags of Convenience and thus losses designated here to SIDS may actually be losses to beneficial vessel owners from other nations. A follow up analysis is currently being undertaken to investigate this result further. Notably, the outcome for the group of FoC countries was consistently the worst, resulting in an average percentage loss under every scenario except when the catches of straddling taxa is assumed to increase by $70 \%$ (Supplementary Table 3 ).

\section{Discussion}

Our analyses suggest that with a $>18 \%$ increase in catch of straddling taxa following a closure of the high seas to fishing, the world as a whole would achieve net gains in catch relative to the status quo. At the country or political entity level, some countries would gain while others would lose, but most coastal countries stand to gain, including in particular, the world's least developed countries. It therefore seems that closing the high seas to fishing would provide net benefits globally, while improving the distribution of such benefits among coastal countries relative to the current situation, where only 10 fishing countries capture most of the high-seas catch and landed values (Table 2).

We acknowledge that our global analysis has incorporated a number of broadly applied assumptions. Most importantly, we have assumed that the catch data used are generally representative of true fisheries catches and that over or under-reporting of catches of straddling taxa is not significant. In addition, we have applied scenarios of increased catches of straddling taxa within EEZs following high-seas closure evenly across all EEZs. Realistically, geographic and interspecific variation exists in both the accuracy of reported data and the potential spillover of biomass from closed high seas areas, though addressing expected ranges of uncertainty is outside the scope of this study. Instead, we provide a foundation for more detailed analyses of the costs and benefits of global high-seas closure.

Whether or not the specific fishing outcomes predicted here would materialize, there would be other significant consequences to closing the high-seas. In general, vessels fishing the high seas travel longer distances, spend longer searching for fish, and therefore incur a higher cost per unit weight of fish than vessels fishing solely within EEZs. This means that closing the high seas would, all else being equal, reduce the burning of fossil fuel and the cost of fishing globally. As of 2000, fishing vessels burned approximately 50 billion $L$ of fuel annually, which accounted for $\sim 1.2 \%$ of global oil consumption and resulted in the direct emission of more than 130 million $t$ of $\mathrm{CO}_{2}$ into the atmosphere ${ }^{21}$. Though these estimates are substantial, they are likely highly conservative as illegal, unreported and unregulated (IUU) fishing activities, many of which occur on the high seas, were not taken into account in these calculations ${ }^{21,22}$. It should also be noted that climate-induced changes in distributions of fish species ${ }^{23}$ would likely affect the economies of tropical developing countries, hence reinforcing our argument for a more equitable distribution of benefits derived from fisheries resources ${ }^{24}$.

An issue that naturally arises from proposals to close the high seas to fishing is how to implement, monitor and control such a large area of the ocean to prevent illegal fishing. Implementing a closure of the high seas would require fundamental reform of ocean governance through a new implementing agreement added to the UNCLOS and 
Table 2 | Top high-seas fishing nations* by average annual landed value (2000-2010)**

Fishing country Average high-seas landed value (million US\$) \% of global landed value Average high-seas catch (thousand $\mathrm{t}$ ) \% of global catch

\begin{tabular}{|c|c|c|c|c|}
\hline Japan & 2,542 & 24 & 807 & 19 \\
\hline South Korea & 1,262 & 40 & 632 & 38 \\
\hline Spain & 742 & 31 & 300 & 33 \\
\hline Chile & 635 & 24 & 988 & 25 \\
\hline China Main & 629 & 5 & 646 & 7 \\
\hline Philippines & 385 & 16 & 328 & 15 \\
\hline France & 349 & 20 & 99 & 17 \\
\hline Total for all countries & 12,047 & & 7,896 & \\
\hline
\end{tabular}

*Note that small pelagic fishes, which are mainly coastal species, were not included in ranking countries.

**Average annual landed values and catches (2000-2010) were taken from the Sea Around Us catch and price database ${ }^{14}$.

***Indonesia makes this list most probably because it provides Flags of Convenience.

by supporting measures within other UN bodies such as the FAO and the Convention on Biological Diversity. Whilst this may be viewed as unrealistic, the expansion of human activities in the high seas may mean that spatial planning will become a necessity in the near future in any case, driving reform of the governance of this area. Ensuring the effective enforcement of a high-seas closure would require cooperation amongst a network of geographically dispersed and technologically equipped coastal States, or the creation of a new global policing agency, established and funded under the UN or alternatively, the International Criminal Police Organization (INTERPOL).

Penalties imposed on violators could help offset additional administrative and operational costs. Amendments to existing legislation could also be introduced to make enforcement possible and straightforward. For example, the International Maritime Organization's International Convention for the Safety of Life at Sea (SOLAS) could be amended so that the mandatory requirement for shipping vessels to carry and actively use an Automatic Identification System (AIS) and to have a mandatory and permanent vessel identification number could also be applied to fishing vessels ${ }^{25}$. These potential options and other questions regarding the logistics of closing the high seas to fishing remain to be explored fully, but the satellite technology for surveillance exists and is currently used by the shipping industry. It just needs to be used to the same extent by the fishing industry as well.

Based on our analysis, we argue that it would be more equitable, and environmentally and economically sensible to close the high seas to fishing, i.e., to turn the high seas into a fish bank for the world. The usual reaction to this argument is that it will lead to massive risks to food security (through reduction in catches), employment, revenues, and profits - but our results suggest that this is unlikely to be the case and that it is likely that the reverse is true.

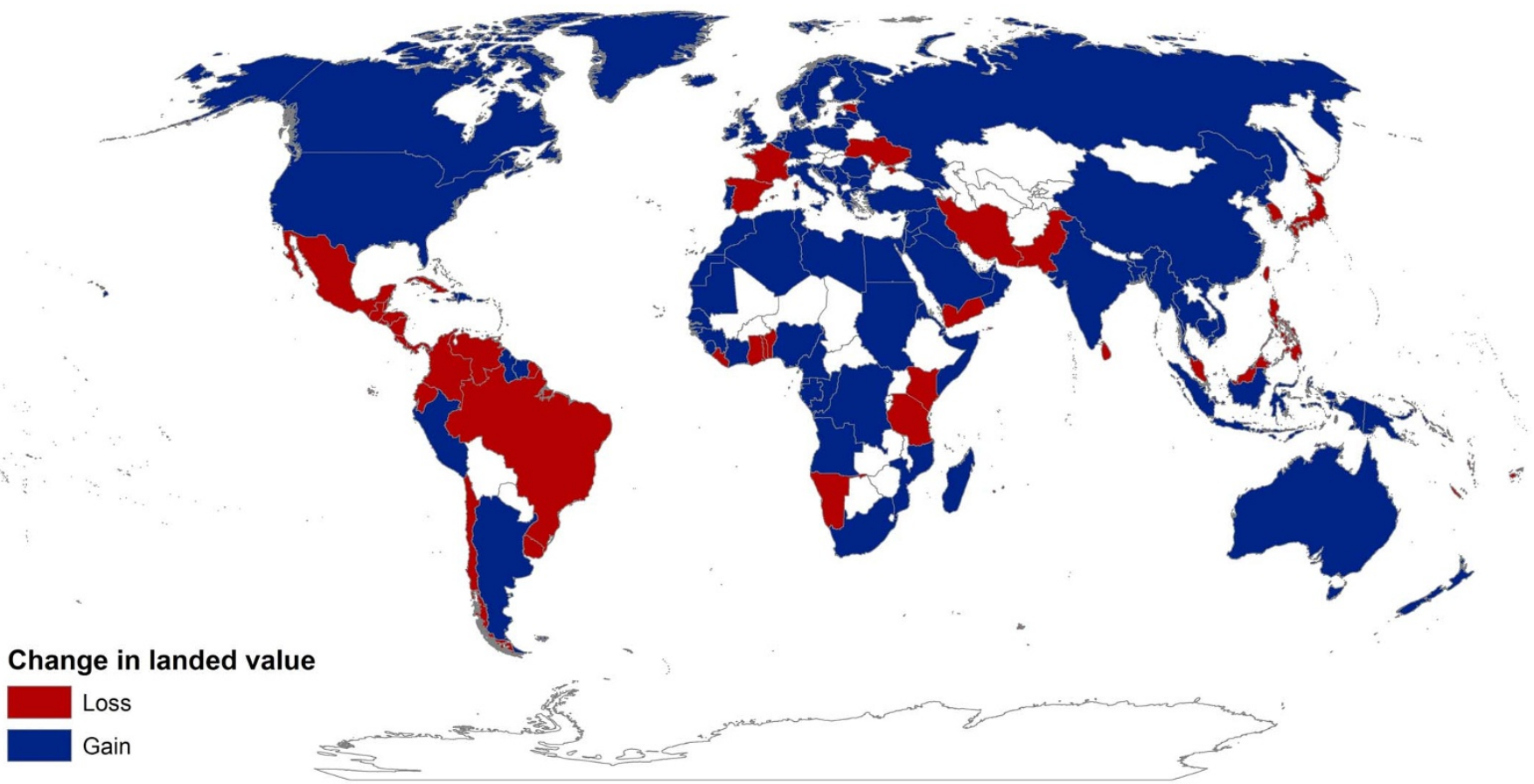

Figure $2 \mid$ Global map of the predicted distribution of gains or losses in total marine fisheries landed values. Based on a scenario where the catch of straddling taxa increase by $18 \%$ following a high-seas closure. Current landed value is the product of catch and ex-vessel price. Catch data were extracted from the Sea Around Us global catch database ${ }^{26}$ (www.seaaroundus.org) while ex-vessel prices were obtained from Sumaila $e t$ al. ${ }^{29}$ and Swartz et al. ${ }^{19}$. The annual catch of straddling taxa by each fishing country was projected to increase by $18 \%$ under the high-seas closure scenario, whereas the catch of non-straddling taxa remains unchanged. Countries with negative and positive change in landed values were labelled "Loss" and "Gain" in the map, respectively. ESRI ArcMap 10.1. was used to create the map. 


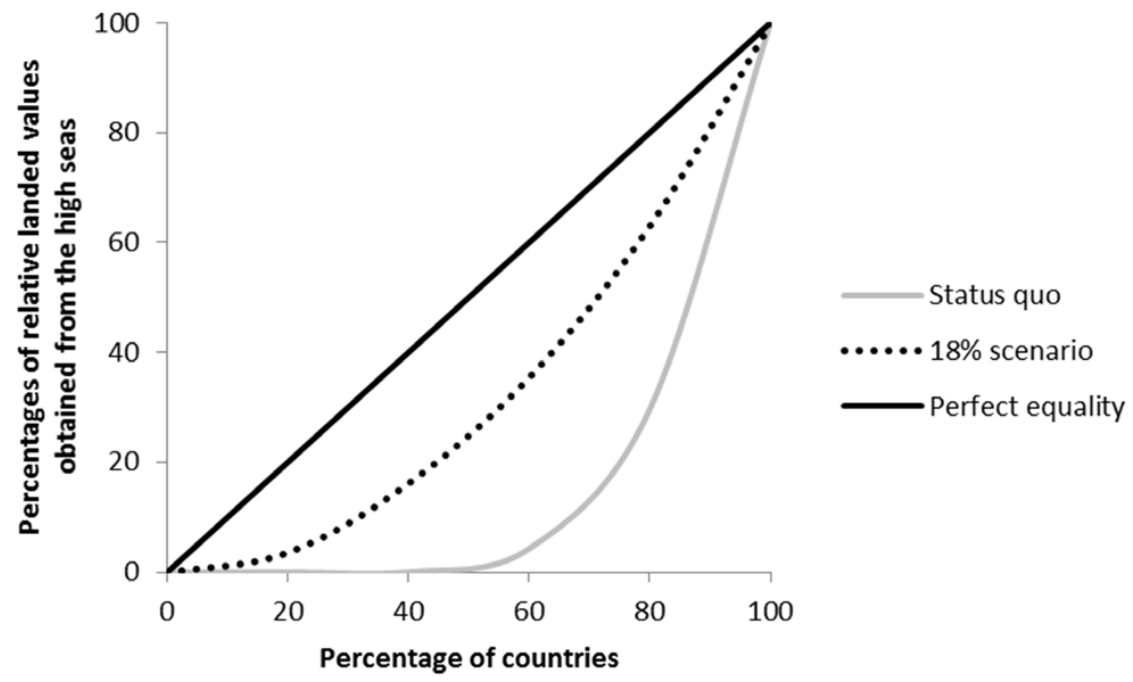

Figure 3 Lorenz curves showing the cumulative percentages of relative landed values obtained from the high seas under the status quo and a closure (to fishing) scenario against the cumulative percentages of countries, starting with the country that obtains the lowest relative landed value. The closure scenario shown assumes that the catch of straddling taxa following the closure increases by at least $18 \%$. Under this scenario, the Gini coefficient drops by $50 \%$, from 0.66 to 0.33 .

\section{Methods}

Data. We used catch data from 2000 to 2010 from the Sea Around Us, which is quality-checked and mapped to a grid of $30^{\prime}$ by $30^{\prime}$ spatial cells ${ }^{26}$. The mapped fisheries landings dataset used was reported global landings from 1950 to 2010 inclusive, and originated from the Food and Agriculture Organization's (FAO) fisheries database, supplemented by its regional datasets, the International Council for the Exploration of the Sea (ICES), regional tuna organizations, the North Atlantic Fisheries Organization (NAFO) and the secretariat of the Convention for the Conservation of Antarctic Marine Living Resources (CCAMLR) ${ }^{26}$

These statistics, after harmonization, were disaggregated into a spatial grid system that breaks down the world's ocean into 180000 cells $\left(0.5^{\circ}\right.$ latitude by $0.5^{\circ}$ longitude), using a rule-based approach based on the geographical distribution of over 1500 commercially exploited fish and invertebrate taxa. Ancillary data were also integrated, such as the fishing agreements regulating foreign access to the EEZs of maritime countries and a database of their observed fishing patterns. The FAO created a database of these agreements called Farisis ${ }^{27}$. We further developed and widely expanded the contents of this database so that it could be used in the spatial allocation process to guide, where possible, the allocation of catches to coastal waters, which have one or more EEZ claims on them. This additional information includes all reports we could locate documenting fishing by one nation in another nation's coastal waters.

Fisheries landings were allocated to spatial cells within the reported statistical area, which were either high seas (not claimed by any country) or in EEZ-claimed waters where the fishing country was known to be fishing and/or have access arrangements pertinent to the reported catch. The proportion of landings assigned to these valid cells was apportioned according to the applicable distribution of the reported species (or group) and the ocean area within the cell. As these data were derived largely from raw data reported by the FAO, they are not strictly 'catches' but largely represent 'landings' only, i.e., the portion that was retained and reported. For each country, the $30^{\prime} \times 30^{\prime}$ spatial cells that comprise their EEZ claim (disputed or otherwise) ${ }^{28}$ were used to determine the mapped landings reported from their EEZ.

Since the last allocation of data (through 2006), there has not been another update on the spatial landings data to include more recent global landings from the FAO. However, the Sea Around Us extended the catch series for the present study based on FAO reported landings from 2007-2010. This was first performed by comparing the complete list of taxa in the Sea Around Us catch database with a list of all taxa occurring in the FAO data from 2007-2010. We then calculated the proportions of each taxon in the Sea Around Us catch database by each fishing country within each EEZ and high seas in an FAO statistical area for 2006. Finally, we used these proportions to allocate the taxon-specific landings in the 2007-2010 FAO data to each EEZ by each fishing country within an FAO statistical area in which that taxon was caught. The results are catch time series for most species that run from 2007 to 2010. The extended catch data from 2007 to 2010 in the Sea Around Us database were allocated to each EEZ and the high seas. These were linked to ex-vessel fish price data ${ }^{19,29}$ for all taxa caught in the global ocean. We then estimated the global average annual catch and landed values for each species/taxon group caught (i) exclusively in the high seas; (ii) exclusively in EEZs; and (iii) in both the high seas and the EEZs (i.e., straddling taxa).

Analysis. We calculated the expected total gains or losses in catch quantity and landed value by country or political entity following a high-seas closure for the scenarios where the percentage increase in EEZ catches of straddling taxa would result in no loss of aggregate global catch and landed value ( $18 \%$ and $20 \%$, respectively). This was accomplished by first subtracting all catches taken from the high seas from the total catches for each year from 2000 to 2010, then multiplying the catches of straddling taxa caught within each EEZ by $18 \%$ and then by $20 \%$ (for both scenarios) for each fishing country. In addition, we calculated the same for scenarios where catches of straddling taxa would increase by $10 \%, 42 \%$ and $70 \%$, as predicted by White \& Costello $^{17}$.

We further analysed gains and losses by different groups of countries: members of the Group of Eight (G8); members of the Organisation for Economic Co-Operation and Development (OECD); the top ten countries that currently catch the most by value in the high seas; member states of the European Union (EU); the Least Developed Countries, as identified by the United Nations (UN); the Small Island Developing States (SIDS), as identified by the UN; and 'Flag of Convenience (FoC) countries', i.e., those for which over $50 \%$ of the fishing vessels that fish under their flag are flying the flag of a state that does not match the state of vessel owner control or residence (Supplementary Table 4). These were identified based on global fishing fleet information provided by Sea-Web in January of 2013 (www.sea-web.com).

We calculated the Gini coefficient for the status quo and the catch-neutral scenario after closure to assess the degree to which the distribution of landed values amongst maritime countries is equitable. For our purposes, the Gini coefficient measures the extent to which the distribution of landed value among maritime countries deviates from a perfectly equal distribution. Lorenz curves fitted the cumulative percentages of relative landed values obtained from the high seas under the status quo and closure (to fishing) scenario against the cumulative number of countries, starting with the country that obtains the lowest relative landed value. The Gini coefficient measures the area between the Lorenz curve and a hypothetical line of absolute equality, expressed as a ratio of the maximum area under the line. Therefore a Gini coefficient of 0 represents perfect equality, while an index of 1 implies perfect inequality.

1. Swartz, W., Sala, E., Tracey, S., Watson, R. \& Pauly, D. The Spatial Expansion and Ecological Footprint of Fisheries (1950 to Present). PLoS ONE 5, e15143 (2010).

2. Milazzo, M. Subsidies in world fisheries: a re-examination. (The World Bank, Washington D.C., United States, 1998).

3. Cullis-Suzuki, S. \& Pauly, D. Failing the high seas: A global evaluation of regional fisheries management organizations. Marine Policy 34, 1036-1042 (2010).

4. Anderson, O. R. J. et al. REVIEW Global seabird bycatch in longline fisheries. Endang Species Res 14, 91-106 (2011).

5. Juan-Jordá, M. J., Mosqueira, I., Cooper, A. B., Freire, J. \& Dulvy, N. K. Global population trajectories of tunas and their relatives. PNAS 108, 20650-20655 (2011).

6. Norse, E. A. et al. Sustainability of deep-sea fisheries. Marine Policy 36, 307-320 (2012).

7. Ramirez-Llodra, E. et al. Deep, diverse and definitely different: unique attributes of the world's largest ecosystem. Biogeosciences 7, 2851-2899 (2010).

8. Roberts, C. M. Deep impact: the rising toll of fishing in the deep sea. Trends Ecol Evol 17, 242-245 (2002).

9. Sumaila, U. R., Zeller, D., Watson, R., Alder, J. \& Pauly, D. Potential costs and benefits of marine reserves in the high seas. Mar Ecol Prog Ser 345, 305-310 (2007). 
10. Gjerde, K. M., Currie, D., Wowk, K. \& Sack, K. Ocean in peril: Reforming the management of global ocean living resources in areas beyond national jurisdiction. Marine Poll Bull 74, 540-551 (2013).

11. Ramirez-Llodra, E. et al. Man and the Last Great Wilderness: Human Impact on the Deep Sea. PLoS ONE 6, e22588 (2011).

12. Hastings, A. \& Botsford, L. W. Equivalence in yield from marine reserves and traditional fisheries management. Science 284, 1537-1538 (1999).

13. Brooks, C. M. Competing values on the Antarctic high seas: CCAMLR and the challenge of marine-protected areas. The Polar J 3, 277-300 (2013).

14. Ban, N. C. et al. Systematic Conservation Planning: A Better Recipe for Managing the High Seas for Biodiversity Conservation and Sustainable Use. Conservation Letters 7, 41-54 (2014).

15. Brooks, C. M. et al. Challenging the right to fish in a fast-changing ocean. Stanf Environ Law J (SELJ) 33, 289-324 (2014).

16. Block, B. A. et al. Tracking apex marine predator movements in a dynamic ocean. Nature 475, 86-90 (2011).

17. White, C. \& Costello, C. Close the High Seas to Fishing? PLoS Biol 12, e1001826 (2014).

18. McWhinnie, S. F. The tragedy of the commons in international fisheries: An empirical examination. J Environ Econ Manage 57, 321-333 (2009).

19. Swartz, W., Sumaila, R. \& Watson, R. Global ex-vessel fish price database revisited: A new approach for estimating 'missing' prices. Environ Resource Econ 56, 467-480 (2013).

20. Chin, G. \& Culotta, E. The science of inequality. What the numbers tell us. Introduction. Science 344, 818-821 (2014).

21. Tyedmers, P. H., Watson, R. \& Pauly, D. Fueling global fishing fleets. Ambio 34 635-638 (2005).

22. High Seas Task Force. Closing the net: Stopping illegal fishing on the high seas. 116 (Governments of Australia, Canada, Chile, Namibia, New Zealand, and the United Kingdom, WWF, IUCN and the Earth Institute at Columbia University, 2006).

23. Cheung, W. W. L. et al. Large-scale redistribution of maximum fisheries catch potential in the global ocean under climate change. Glob Change Biol 16, 24-35 (2010).

24. Sumaila, U. R., Cheung, W. W. L., Lam, V. W. Y., Pauly, D. \& Herrick, S. Climate change impacts on the biophysics and economics of world fisheries. Nature Clim. Change 1, 449-456 (2011).

25. Rogers, A. D. \& Sack, K. Not seeing the wood for the trees. Global Policy 3, 515-516 (2012).

26. Watson, R., Kitchingman, A., Gelchu, A. \& Pauly, D. Mapping global fisheries: sharpening our focus. Fish and Fisheries 5, 168-177 (2004).

27. FAO. FAO's fisheries agreements register (FARISIS). (Committee on Fisheries, 23rd Session, Rome, Italy, 1999).
28. Nauwere, N. D., Vanhoorne, B., Souza Dias, F., Hernandez, F. \& Mees, J. Marine Regions - Shapefiles. Marine Regions (2014)at <http://www.marineregions.org/>, date of access: 30/10/2014.

29. Sumaila, U. R., Marsden, A. D., Watson, R. \& Pauly, D. A global ex-vessel fish price database: Construction and applications. J Bioecon 9, 39-51 (2007).

\section{Acknowledgments}

U.R.S. and D.D.M. would like to acknowledge the support of the Global Ocean Commission, Somerville College, Oxford University, OceanCanada and the Social Sciences and Humanities Research Council of Canada (SSHRC). We also thank The Pew Charitable Trusts whose support of the Sea Around Us and Global Ocean Economics projects at the University of British Columbia made the current analysis possible. Conservation International funded the extension of the catch data set from 2007 to 2010 as part of the Ocean Health Index Project, which was kindly performed by Dr. Kristin Kleisner. Finally, we thank Crow White and Christopher Costello for their valuable comments on earlier versions of the paper.

\section{Author contributions}

U.R.S. conceived the paper, conducted the analysis and wrote the paper. V.W.Y.L. and D.D.M. conducted the analysis and co-wrote the paper. L.T., R.W., D.Z., W.W.L.C., I.M.C., A.D.R., C.R. and E.S. contributed to the analysis and co-wrote the paper. D.P. leads the Sea Around $U s$, which provided much of the data used for this contribution, and he co-wrote the paper.

\section{Additional information}

Supplementary information accompanies this paper at http://www.nature.com/ scientificreports

Competing financial interests: The authors declare no competing financial interests.

How to cite this article: Sumaila, U.R. et al. Winners and losers in a world where the high seas is closed to fishing. Sci. Rep. 5, 8481; DOI:10.1038/srep08481 (2015).

This work is licensed under a Creative Commons Attribution-NonCommercialShareAlike 4.0 International License. The images or other third party material in this article are included in the article's Creative Commons license, unless indicated otherwise in the credit line; if the material is not included under the Creative Commons license, users will need to obtain permission from the license holder in order to reproduce the material. To view a copy of this license, visit http:// creativecommons.org/licenses/by-nc-sa/4.0/ 